\title{
Konfliktustípusok és konfliktuskezelés magyar egészségügyi dolgozók körében
}

\author{
Csupor Éva ${ }^{1}$ - Kuna Ágnes ${ }^{2}$ - Pintér Judit Nóra ${ }^{3}$ \\ Kaló Zsuzsa ${ }^{4}$. Csabai Márta ${ }^{3}$
}

\begin{abstract}
'Szegedi Tudományegyetem, Általános Orvostudományi Kar, Gyermek- és Ifjúságpszichiátriai Osztály, Szeged ${ }^{2}$ Magyar Tudományos Akadémia-Pázmány Péter Katolikus Egyetem, Információs Technológiai és Bionikai Kar, Budapest

${ }^{3}$ Szegedi Tudományegyetem, Bölcsészettudományi Kar, Pszichológiai Intézet, Szeged

${ }^{4}$ Eötvös Loránd Tudományegyetem, Pedagógiai és Pszichológiai Kar, Tanácsadás Pszichológiája Tanszék, Budapest
\end{abstract}

Bevezetés: Az egészségügyi dolgozók egymás közti kommunikációja, konfliktuskezelése, a megfelelő együttmúködés kiemelkedően fontos a betegellátás sikerességében. Célkitüzés: A bemutatott kutatás egy nemzetközi összehasonlító felmérés része. A vizsgálat célja, hogy feltérképezze az egészségügyi dolgozók körében felmerülő konfliktusokat. Módszer: A magyar felmérésben 73 egészségügyi dolgozóval vettünk fel félig strukturált interjúkat a nemzetközi interjúprotokoll szerint, amely során munkahelyi konfliktushelyzetek elmesélésére kértük a résztvevőket. 30 interjút (15 orvos és 15 nővér) Atlas.ti 7 kvalitatív szoftverelemző programmal elemeztünk. A konfliktustörténeteket négy fó kategória mentén vizsgáltuk, ezek a következők: a konfliktusok forrásai, típusai, hatásai és a használt konfliktuskezelési stratégiák. Eredmények: Az interjúkból megismerhető az egészségügyben részt vevők munkahelyi konfliktusokkal kapcsolatos személyes tapasztalata. Kiemelendő a hierarchia és az implicit munkaszervezés jelentős befolyása, fóleg az orvosok körében. Az elkerülő konfliktuskezelés miatt a konfliktusok egy része megoldatlan marad, ami negatív hatással jár az egyénre és a csoportra nézve is. Következtetések: Eredményeink segítségével a késóbbiekben kialakítható egy egészségügyre specifikus konfliktuskezelési intervenció. Orv. Hetil., 2017, 158(16), 625-632.

Kulcsszavak: egészségügy, konfliktus, kommunikáció, hierarchia, konfliktuskezelés

\section{Types of conflicts and conflict management among Hungarian healthcare workers}

Introduction: Efficient communication, conflict management and cooperation are the key factors of a successful patient care. Aim: This study is part of an international comparative research. The aim of this study is to unfold conflicts among healthcare workers. Method: 73 healthcare workers were interviewed using a standardized interview protocol. The in-person interviews used the critical incident method. 30 interviews ( 15 doctors, 15 nurses) were analysed with the Atlas.ti 7 content analysis software. The sources, types, effects of conflicts and conflict management strategies were investigated. Results: The content analysis unfolded the specificities of conflicts in healthcare based on personal experiences. Organizational hierarchy was a substantial source of conflict, especially among physicians, which originates from implicit rules. As a result of the avoiding conflict management the conflicts remain partly unresolved which has negative individual and group effect. Conclusions: Our conceptual framework helps to develop a proper intervention specific to healthcare.

Keywords: healthcare, conflict, communication, hierarchy, conflict management

Csupor, É., Kuna, Á., Pintér, J. N., Kaló, Zs., Csabai, M. [Types of conflicts and conflict management among Hungarian healthcare workers]. Orv. Hetil., 2017, 158(16), 625-632.

(Beérkezett: 2017. február 15.; elfogadva: 2017. március 13.) 


\section{Rövidítések}

$\mathrm{D}=$ orvosinterjúból származó idézet (az utána következő számok az interjú számát jelölik, például: $\mathrm{D} 2=2$. számú interjú, orvos a vizsgálati személy); eü. = egészségügy; $\mathrm{N}=$ nővérinterjúból származó idézet (az utána következő számok az interjú számát jelölik; például: N29 = 29. számú interjú, nővér a vizsgálati személy); v. sz. = vizsgálati személy

Konfliktus akkor jön létre, ha 1. egy személy érdekei öszszeütközésbe kerülnek egy másik személyével, és ez megakadályozza saját céljainak elérését; vagy 2 . több személynek van igénye ugyanarra az eróforrásra, de az erőforrások végesek; avagy 3. a személy értékrendje és attitűdje összeegyeztethetetlen másokéval [1]. A konfliktusok egy szervezeten belül több szinten is megjelenhetnek: Rabim és Bonoma [1] szerint megkülönböztethetünk személyen belüli (belső), valamint személyközi konfliktust. A személyközi konfliktusokon belül elkülöníthetünk csoporton belüli, továbbá csoportok és szervezetek közötti konfliktust. A konfliktusok minden munkahelyi környezetben (elkerülhetetlenül) előfordulnak, így az egészségügyben is. Az ellátás többféle szakma együttmúködését igényli, amit megnehezít a munkához társuló magas stressz, így az egészségügyi dolgozók között a konfliktusok előfordulása fokozott mértékü [2]. A konfliktusokat általában negatívan értékeljük, de valójában csak a konfliktusok elkerülése vagy tartós fennállása jár negatív következményekkel. A konfliktusok pozitív hatásai sokszor háttérbe kerülnek, annak ellenére, hogy a funkcionális konfliktusok a különféle nézőpontok ütköztetése, megvitatása révén fontos változásokat segíthetnek elő. A konfliktushoz kapcsolódó negatív asszociáció következménye a konfliktuskerülésre vagy -elnyomásra való törekvés, amely általánosan elterjedt $[3,4]$. Az egészségügyben a megoldatlan konfliktusok számos negatív következménnyel járhatnak, például csökkent önértékelés, gyakoribb munkahelyi hiányzások, munkahelyváltás [5]. Ezek közül azonban a legveszélyesebb a betegellátásra gyakorolt negatív hatás: a hibázás kockázatának növekedése, a betegbiztonság csökkenése, a beteg állapotának rosszabbodása $[4,5]$.

Az egészségügyi dolgozók (orvosok, nővérek, ápolók, egyéb személyzet) egymás közti konfliktuskezelése, kommunikációja, a megfelelő együttmúködés kiemelkedően fontos a betegellátás sikerességében. Az együttmüködésre épülő szervezeti múködés csökkenti a hibák előfordulási valószínúségét, növeli a hatékonyságot, a betegbiztonságot és nem utolsósorban csökkenti az ellátás költségét [6]. Az említett tényezők miatt kiemelten fontos az egészségügyben előforduló konfliktusok sajátosságainak megismerése és ezáltal a megfelelő stratégia kidolgozása.

Hazánkban eddig kevés szisztematikus vizsgálat foglalkozott az egészségügyi konfliktusok feltárásával, holott ez nagy hatással van az intézmények múködésére és annak hatékonyságára. A nemzetközi projekten belül ezért is tartottuk kiemelkedően fontosnak a munkahelyi konfliktusok egészségügyre jellemző sajátosságainak megismerését. Együttmúködésben a University of Washington és a Université de Genève kutatócsoportjaival, közös interjúprotokollon alapuló narratív, kvalitatív kutatást végzünk az egészségügyi dolgozók (orvosok, nővérek) körében. A kutatás célja a konfliktus forrásainak, típusainak és hatásainak feltárása mellett az alkalmazott konfliktuskezelési stratégiák megismerése. Fontosnak tartjuk a dolgozók saját élményének, nézőpontjának megismerését, mivel ezáltal a későbbiekben lehetővé válhat egy egészségügyre specifikus konfliktuskezelési módszer, illetve intervenció kidolgozása. A kutatócsoportok eredményeinek összehasonlítása pedig lehetővé teszi a kultúrspecifikus tényezők és mintázatok leírását is. Jelen tanulmányunkban a magyar mintán történt felmérés eredményeit mutatjuk be.

\section{Módszer}

\section{Résztvevők}

A vizsgálatban összesen 73 egészségügyi dolgozó (49 orvos és 24 nôvér) vett részt, akik budapesti és vidéki kórházakban, klinikákon, valamint az alapellátásban látnak el gyógyító tevékenységet. Az orvosok különböző osztályokon dolgoznak, a nővérek egy osztályról kerültek a vizsgálatba.

\section{Eszközök}

A vizsgálati személyekkel félig strukturált interjút vettünk fel, amely a nemzetközi interjúprotokoll magyar változata (lásd Melléklet). Az interjúban megkértük a vizsgálati személyeket (v. sz.), hogy mondjanak el egy velük történt konkrét konfliktushelyzetet, majd rákérdeztünk annak körülményeire, okaira, kezelésére és következményeire. Ezután opcionálisan további (általában legalább még egy) konfliktusszituáció elmondására kértük a v. sz.-eket. Az interjúkat hangfelvevővel rögzítettük, és szó szerinti átiratokat készítettünk. A v. sz.-ek beleegyező nyilatkozatot írtak alá, garantáltuk számukra az anonimitást. Ezenkívül a következő adatokat rögzítettük róluk: nem, életkor, osztály, beosztás, mióta dolgozik az adott intézményben és mióta dolgozik az egészségügyben.

\section{Kvalitatí elemzés és statisztikai eljárások}

A kezdeti kódolási rendszer kialakítása offline kvalitatív tartalomelemzéssel (két kódoló: 2. és 3. szerző) történt 15 random interjú alapján, majd finomítottuk a kategóriákat a nemzetközi együttmúködő partnerek kódolási rendszerének, valamint a konfliktus-szakirodalomnak megfelelően. 
A kódolás második lépésében két független kódoló (1. és 2. szerző) tesztelte és módosította a kódolási rendszert öt-öt interjú alapján. A harmadik lépésben pedig ugyanezen szerzők 15 nővérrel és 15 orvossal készült interjút kódoltak. A nővérinterjúkat ugyanazon a kórházi osztályon ugyanaz az interjúkészítő vette fel. Az orvosokkal készített interjúk több különböző kórházi osztályon, klinikán és háziorvosi rendelőben készültek, amelyeket a második kódoló (1. szerző) vett fel.

Az interjúkat az Atlas.ti 7 kvalitatív szoftverrel elemeztük, amely lehetôvé teszi a strukturált adatokon történő (például szöveg, videó) szisztematikus vizsgálatokat, valamint rejtett jelenségek és összefüggések felfejtését, leírását is.

\section{Eredmények}

Az elemzésbe bevont interjúkban összesen 126 konfliktustörténet jelent meg, amelyekből 39 történet általános reflexió (nem specifikus konfliktushoz köthető). Az általános reflexió általában az egészségügyre vagy az abban megjelenő konfliktusokra, illetve személyes konfliktusmegoldási stílusra vonatkozott. Összesen 87 konkrét konfliktustörténet jelent meg, 46 az orvosokkal, 41 a nővérekkel készített interjúkban.

\section{Az offline kvalitatív tartalomelemzés alapján kialakitott konfliktuskategóriák}

A kvalitatív tartalomelemzés alapján (a konfliktus szerkezetét követve) négy fó kategóriába kódoltuk az interjúkban elmondott konfliktustörténeteket. Ezek: 1. A konfliktus forrásai. 2. A konfliktus tipusai. 3. Konfliktuskezelési stratégiák. 4. A konfliktus hatásai (1. ábra). A következókben a kategóriákat és az alkategóriákat mutatjuk be.

\section{A konfliktus forrásai}

A konfliktus forrásait három alkategóriára bontottuk: egyéni, személyközi és szervezeti szintü konfliktusokra [7].

Az egyéni konfliktusforrás kategórián belül megkülönböztettünk két további alkategóriát. A személyes faktorok arra utalnak, hogy a konfliktus az egyén személyiségéből, illetve élethelyzetéből adódik, továbbá összefüggésben áll a megküzdési stílussal (például: „Benne se volt annyi tartás, hogy akkor az, oké, akkor a kötelezőnek gondolt képzésre elmegy és a másik kettőt vagy egyiket átszervezi [...].” D3). A veszteségfeldolgozásból adódó nehézségek alkategóriába soroltuk azokat a válaszokat, amikor a konfliktus a munka során fellépő veszteségekkel (például

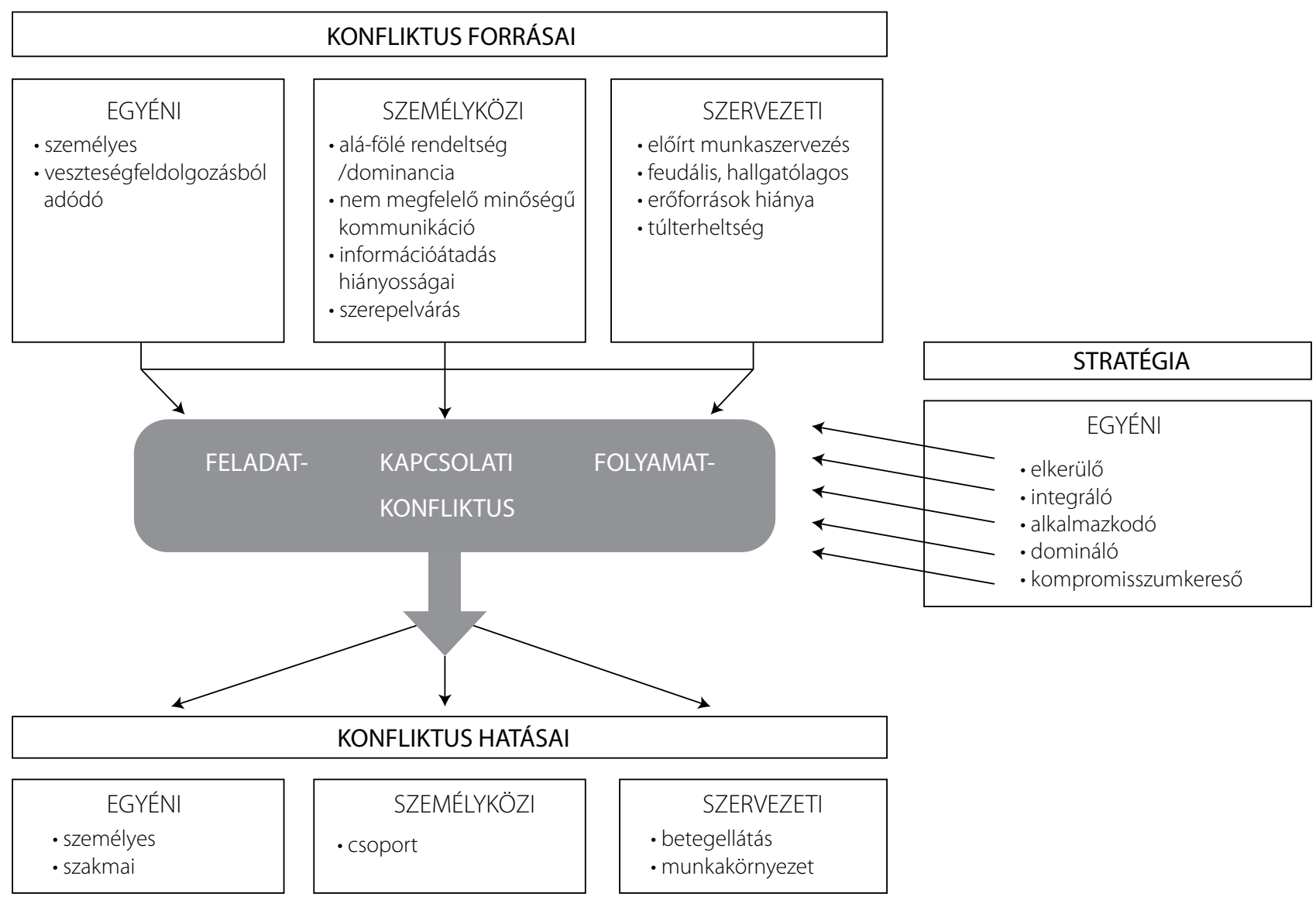

1. ábra

| A tartalomelemzés alapján kialakított konfliktuskategóriák 
haláleset), illetve azok feldolgozásával áll összefüggésben (például: „Idő kell ahhoz, hogy feldolgozzam. '76 óta vagyok ápoló, de ez nem megy. Nehéz, nehéz.” N29).

A következő kategória a személyközi szint, ahol a konfliktus interperszonális kapcsolatra vezethető vissza. Ezen belül három alkategóriát azonosítottunk, alá-fölé rendeltség/dominancia (hatalommal összefüggésben), amikor a konfliktus a személyek között fellépő alá-fölé rendeltségi viszonyból adódik. Ez szakmai és személyes szinten is jelentkezhet (például: „Nyilván ezt a részét a konfliktusnak én nem tudom feloldani, mert annyival fölöttem van az a valaki, aki azt mondta, hogy nem írja meg [...]." D7).

A kommunikáció kategóriája bármilyen kommunikációs problémára vonatkozik, ezen belül két további alkategóriát azonosítottunk: nem megfelelo" minóségü kommunikáció (személyes szinten), amikor a konfliktus a kommunikáció minőségével és az ezáltal keletkezett érzelmekkel (harag, agresszió, türelmetlenség) hozható összefüggésbe (például: „De én neked nem segítek, mert legutóbb ugye miattad nem tudtam elmenni a továbbképzésre." D3), illetve az információátadás hiányosságai (szakmai szinten), ahol a konfliktus a hiányos kommunikációból, a nem megfelelő információátadásból adódik (például: „Lejött az értekezletről, senkivel semmit nem közölt, velem sem. Többiekkel sem, tehát nem tudtuk, hogy intézményi szinten most akkor mirôl van szó [...]." D10). Az utolsó alkategória a szerepelvárás nevet kapta, amelyben a konfliktus abból adódik, hogy a gyógyításban részt vevők (beleértve a beteget is) egymással nem az elvárt szerep szerint viselkednek, továbbá az elvárt szerepnek nem tesznek eleget (például: „Azt mondja, nem szeret velem ambulálni, mert ö... én egy csomó beteget visszahívok kontrollra [...], és ezáltal közbe neki kell az új betegekből arányaiba többet néznie.” D3).
A harmadik alkategóriába a szervezeti konfliktusok tartoznak, amelyek az egészségügy, illetve az adott intézmény elóírásaival, szabályaival állnak kapcsolatban. Ezek lehetnek rögzített, illetve gyakorlatban élő szokásjogok is. Az elöirt munkaszervezés alkategória szerint a konfliktus az explicit módon leírt szabályokból, illetve egyes kérdések (felelősségi körök, szabályok) tisztázatlanságából adódik (például: „Nagyon sokszor van ez így nálunk, hogy nincs kimondva, hogy ez meg ez kinek a feladata [...]." D7). A hallgatólagos, ,feudális" alkategória szerint a konfliktus nem leírt, azaz implicit szabályokból adódik, amelyek bevett gyakorlatként irányítják a munka szervezését, beosztását, elvégzését (például: „Nagyon sok feladatot kapott, ami nem az ő feladatköre és így próbál könnyíteni, hogy nyilván a fiatal kollégának adja át [...].” D13). Az erőforrások hiánya alkategóriában a konfliktusokat az anyagi megbecsülés hiánya, illetve az intézmények nem kielégítő financiális helyzete okozza (például: „Na, de egy politraumatizált beteg, ha fekszik az ágyban, és annak nincs légkondicionálás, vagy a sterilizálóban nincs és mérlegre teszem a kettőt, hogy hova veszek először.” D8). Végül a túlterheltség kategóriában a konfliktus a túlzott mennyiségú munkából adódik (például: „Tulajdonképpen azért nem magyaráztam el, mert nem volt rá időm [...].” D7).

$\mathrm{Az}$ elemzett interjúkban (2. ábra) mind az orvosok, mind a nővérek körében a személyes faktorok és a nem megfelelö minóségü kommunikáció jelenik meg a konfliktusok fő forrásaként. Kiemelendő konfliktusforrás az orvosok körében: elöirt munkaszervezés, szerepelvárás és túlterheltség. A nővérek esetében viszont a túlterbeltség gyakrabban észlelt konfliktusforrás, mint az eloírt munkaszervezés és a szerepelvárás. Az orvosok egymás közötti konfliktusaiban (orvos-orvos közötti konfliktus) a dominanciát több alkalommal észlelik konfliktusforrásként,

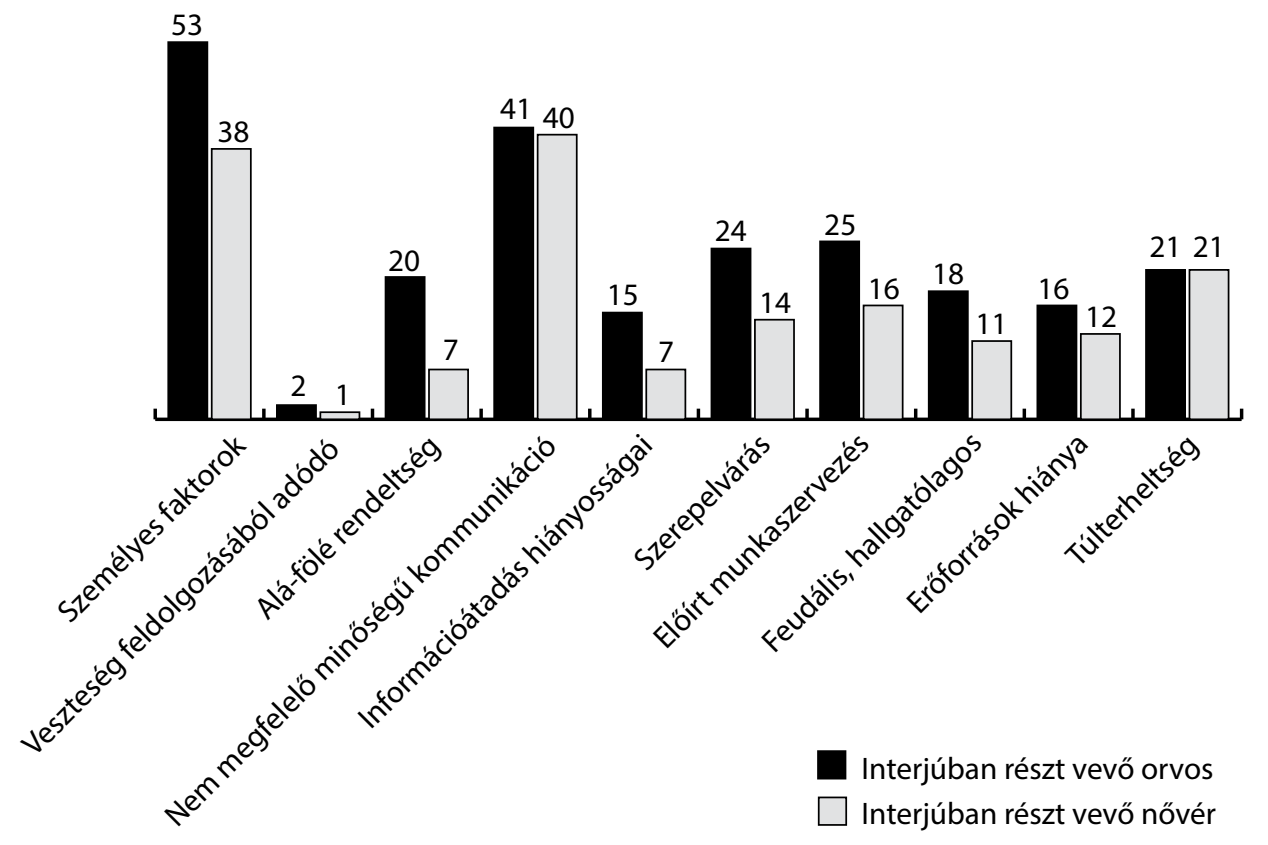


mint a nővérek, aminek hátterében feltehetően a nagyobb fokú hierarchia állhat. Ennek következménye lehet a hallgatólagos, „feudális” szabályok erős befolyása az orvosok közötti konfliktusokban. A konfliktusok forrásainál megfigyelhető, hogy általában nem egyetlen tényező, hanem a fentiek valamilyen együttállása jellemző.

\section{A konfliktusok típusai}

A konfliktusokat a szakirodalom [8-10] alapján három típusra osztottuk: feladat-, kapcsolati és folyamatkonfliktusokra.

A feladatkonfliktus olyan nézeteltéréseket foglal magába, amelyek a feladat tartalmát és kimenetét érintik. A konfliktusok közül a legkonstruktívabb, affektív komponenstől mentes. Ezt a konfliktustípust két további alkategóriára osztottuk: betegellátáshoz köthetó feladatkonfliktus, amely során az egyet nem értés a feladat tartalmával és kimenetelével kapcsolatos (például: „Amit korábban nem operáltunk, mert idős, hát [...] nemegyszer 80 fölöttieket is operálunk." D9; az adott páciensnél melyik terápiás módszer a legmegfelelőbb). Az egyéb feladatkonfliktus a csoport egyéb, nem betegellátáshoz kapcsolódó feladatait érinti (például oktatási feladat).

A kapcsolati konfliktus személyi összeférhetetlenségre, ellentétekre utal, érzések is megjelennek benne, jellemzően személyiségbeli, érték- és normabeli különbségekből adódik, például: két orvos között, az egyiket a segíteni akarás, a másikat a hálapénz motiválja. Ez a konfliktustípus a csoport múködésére nézve a legkárosabb, a kutatások szerint egyértelmúen negatívan befolyásolja a csoport produktivitását.

A folyamatkonfliktus a feladat teljesítésével kapcsolatos nézeteltéréseket jelenti, ez az úgynevezett 'hogyan?' konfliktusa. Ez jelenthet feladat, szolgálat vagy forrás delegálása kapcsán kialakuló ellentétet, például kinek milyen felelőssége van a dologban, megegyezés a határidőben, szerepelosztás, időbeosztás, kinek hány beteget kell ellátnia. A munka végrehajtásával, kivitelezésével kapcsolatos konfliktus megjelenhet a csoport szintjén, ez a csoportfolyamatkonfliktus (például: „Soha nem tudtuk feloldani, mert más volt a hozzáállásunk a dolgokhoz, de ez hosszú távon sokkal kevesebb beteget látott el, mint én, de benne ez konfliktusként még így is megfogalmazódott [...]." D3), vagy szervezeti szinten, ez a szervezeti folyamatkonfliktus (például: „Mindenki kisgyerek mellől inkább jobban örülne annak, hogy napi nyolc órában dolgozni, hétvége szabad [...].” N19). A magas szintü folyamatkonfliktus akadályozza a csoport múködését.

Az elemzés alapján elmondható, hogy a betegellátáshoz köthető feladatkonfliktusok okozzák a legnagyobb problémát az egészségügyi dolgozóknak. Hasonló nehézséget jelentenek a kapcsolati konfliktusok. A feladat- és folyamatkonfliktus sok esetben nagyon nehezen elválasztható, és esetenként érzelmi töltettel is bír. A három konfliktustípus tehát nem minden esetben tisztán jelenik meg.

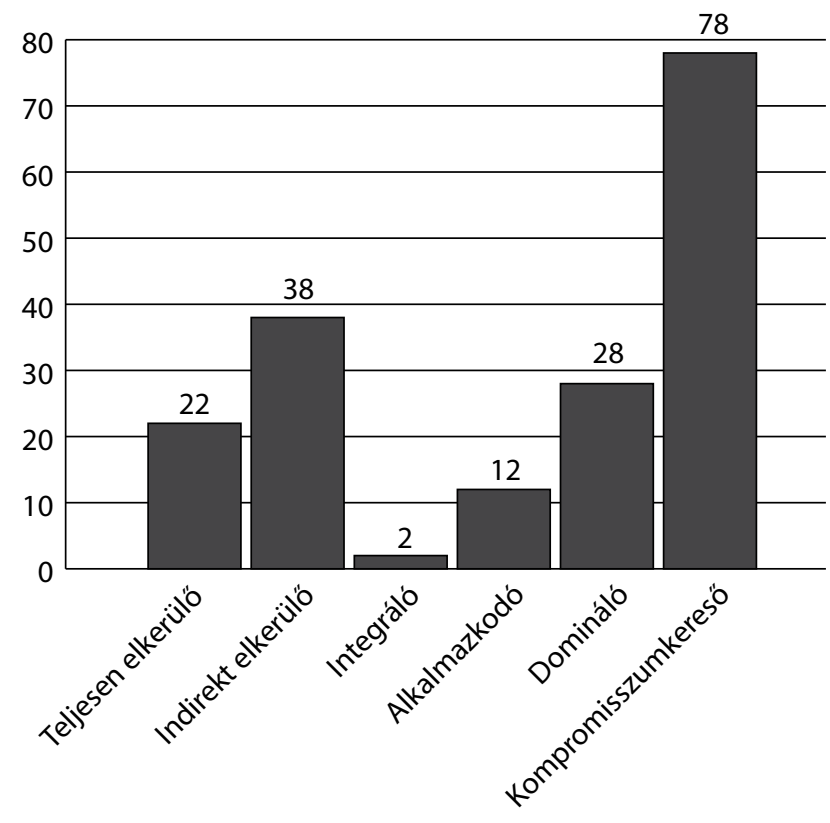

3. ábra $\quad$ Konfliktuskezelési stratégiák

\section{Konfliktuskezelési stratégiák}

A konfliktuskezelés során két fó attitűd különíthető el, az egyik a konfliktusmegoldásra törekvö, a másik pedig az elkerülö attitüd.

Az elemzett mintában az elkerülő stratégiát két további alcsoportra osztottuk: teljesen elkerüló és indirekt elkerüló (3. ábra). A teljesen elkerüló esetben a személy a konfliktust teljes mértékben elkerüli, nem kooperál és nem is beszél róla, így sem a saját, sem a másik érdekei nem érvényesülnek (22 eset a vizsgált anyagban). Az indirekt elkerülö stratégiát (38 eset a vizsgált anyagban) alkalmazó személy nem ahhoz fordul, akivel a konfliktus kialakult (például másokkal beszéli meg), vagy késlelteti a konfliktuskezelést (például később a megbeszélésen mások elött hozza elö).

A konfliktusmegoldásra törekvő stratégiákat a szakirodalom [11-13] alapján az alábbi csoportokba soroltuk: integráló, alkalmazkodó, domináló, kompromisszumkereso" (3. ábra). Az általunk vizsgált egészségügyi dolgozók körében az integráló stratégia fordult elő a legritkábban (két eset), ami összefüggésben állhat azzal, hogy ez igényel a legtöbb időt és energiát a felek részéről. Az alkalmazkodó stratégiát csak ritkán használták az általunk vizsgált egészségügyi dolgozók (12 eset). A domináló konfliktusmegoldási mód már gyakrabban (28 eset) fordult elő a mintánkban, ami szintén az erôs hierarchiát jelzi az egészségügyön belül. A kompromisszumkeresö stratégia fordult elő a leggyakrabban (78 eset) a résztvevők önbevallása alapján.

Hasonló eredményeket találtunk a konfliktus kimenetelét vizsgálva (4. ábra), ugyanis az interjúalanyok a legtöbb esetben megoldódott konfliktusokról számoltak be. Ezzel szemben a megoldatlan konfliktusok száma alacsonyabb volt mind az orvosok, mind a nővérek között. Ha azon- 


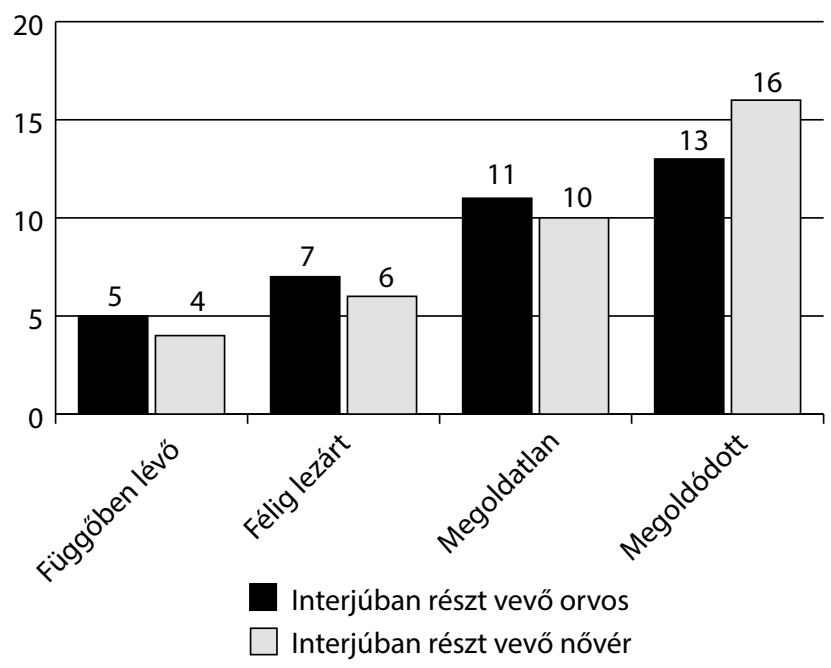

4. ábra |A konfliktusok kimenetele

ban figyelembe vesszük a félig lezárt konfliktusokat is, akkor már elmondható, hogy a megoldatlan konfliktusok valamivel nagyobb arányban vannak jelen. A félig lezárt konfliktusok esetében a konfliktus valamilyen külső ok (például a munka miatt másra kell figyelni, munkahelyváltás) miatt marad lezáratlan és megoldatlan. Néhány esetben beszámoltak függőben lévő konfliktusról, ezek a konfliktusok a közelmúltban zajlottak és mind ez idáig lezáratlanok, tehát a felek még dolgoznak a megoldáson.

\section{A konfliktusok hatásai}

A konfliktus hatásait csakúgy, mint a forrásait, egyéni, személyközi és szervezeti szinten elemeztük.

Egyéni szinten elkülöníthető a személyes és a szakmai hatás, hiszen a konfliktus befolyásolhatja az egyén érzelmi, hangulati állapotát, viselkedését, valamint a szakmai életpályáját is. A személyes hatás érvényesülhet rövid (például érzelmi hatás: harag, szomorúság; mások elkerülése) és hosszú távon is (például életminőség romlása: betegségek kialakulása, kiégés). A szakmai hatás megjelenhet szakmai leértékelés vagy sikertelenség formájában, ami a későbbiekben szakterület- vagy munkahelyváltáshoz is vezethet.

Személyközi szinten a konfliktus hatása csoporthatásként értelmezhető, amely a teamen belüli vagy adott esetben a teamek közötti (például két kórházi osztály, alapellátás és szakellátás közötti) együttmúködést befolyásolja, így a bizalom csökkenhet és a munkahelyi kapcsolatok megromolhatnak (például: „Nyilván ugye egy ilyen félrecsúszott konfliktushelyzet után nehezebben állnak egyenesbe. Tehát azért az fontos, hogy bármenynyire próbáljuk mi ezt felülról vagy felsőbb pozícióból ezt a konfliktust megoldani [...], azért az egymáshoz való viszonyukat egy darabig mindenképp meghatározza.” D3).
Szervezeti szinten a konfliktus befolyással lehet a betegellátásra és a munkabelyi környezetre. A betegellátásra való hatás kategória definíciója szerint beletartozik a munkavégzés minőségére gyakorolt hatás, amely az egészségügyben általában a betegellátást jelenti, de egyéb feladatokat is érinthet (például hatékonyságcsökkenés, a betegellátás nem megfelelő időben történik, betegbiztonság csökken; „Valamelyik beteg úgy nem mondja, de valamelyiket úgy megvisel, hogy ô nem tehet róla [...]." N20). A munkakörnyezetre való hatás következtében nem megfelelő munkakörnyezet jön létre, amelyben potenciálisan megnövekszik a hibák kockázata, és a munkahelyi légkör negatívvá válhat (például: "Rossz légkör, ilyen feszültség igen, amire azt mondják, hogy megáll a bicska a levegőben [...].” Dl).

Mindezek mellett, ahogyan a bevezetőben említettük, a konfliktusok pozitív hatásúak is lehetnek, ez azonban vizsgálati anyagunkban egyetlen egy interjúban jelent meg ( Nagyon pozitív megoldása volt a konfliktusoknak, teljesen megérte, mai napig azt mondom, az egyik legjobb döntés volt az osztályon, abszolút nincs szükségünk vezető főnővérre [...] igazából nem csinálta a dolgát, csak nehezítette az osztályon a békét.” Dl0).

Eredményeink azt mutatják, hogy a személyes hatás a leggyakoribb az egészségügyben, míg a többi hatásról jóval kisebb arányban számoltak be a résztvevők (5. ábra). Feltehetően a személyes hatás a legnyilvánvalóbb az egyének számára, ezek közül is a rövid távú (például érzelmi hatás, stressz) az, amely a legtöbb esetben megfigyelhető. Az egyéb következményeket az önbeszámolóban ritkábban említik a résztvevők. Kiemelendő a betegellátásra való hatás, amely feltehetően alulreprezentált az interjúkban. Ez ellentmond a szakirodalmi adatoknak, amelynek oka lehet, hogy az interjúk szubjektív nézőpontot tükröznek, és az egészségügyi dolgozók egyfajta tabuként kezelték azt, hogy a konfliktusok a betegekre negatív hatással lehetnek. Úgy tûnik, mintha számukra ez elfogadhatatlan következmény lenne, ezért tagadják jelenlétét.

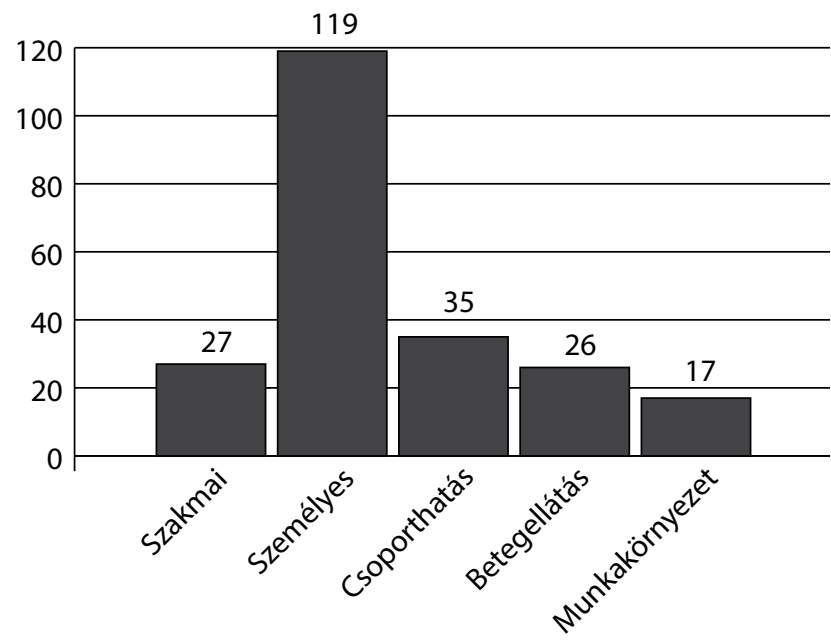

5. ábra $\quad$ A konfliktusok hatása 


\section{Megbeszélés}

Az egészségügyi dolgozók körében megjelenő konfliktusok kiemelt problémát jelentenek mind az egyénre, mind a csoportra és a szervezetre nézve. A konfliktusokról való általános vélemények gyakran megjelentek a résztvevők körében, ami jelzi a kérdés fontosságát, azonban a konfliktusok komplexebb megértése már nagyobb nehézséget jelentett (az interjúalanyok facilitálása szükséges). A kutatás segítségével megismerhetővé váltak az egészségügyet jellemző munkahelyi konfliktusok. Az egészségügyi dolgozók narratívái, valamint a konfliktussal foglalkozó szakirodalom figyelembevételével részletes keretrendszert dolgoztunk ki.

A konfliktus forrásainak elemzése segítséget nyújthat egy olyan konfliktuskezelési módszer kidolgozásához, amely egyéni, személyközi és szervezeti szintű lépésekre bontható. A konfliktusforrások közül kiemelendő a dominancia, azaz a hierarchikus rendszer jelentős befolyása, amellyel együtt jár egyfajta feudális szervezeti müködés és az implicit szabályok jelenléte. A munkapszichológiában azonosított fóbb konfliktustípusok (feladat, kapcsolati, folyamat) az egészségügyben is megjelennek. A feladatkonfliktus ötletek, vélemények közötti különbségekből adódik. A feladathoz tartozó értékek, szükségletek és érdekek különbségét jelenti. A folyamatkonfliktus a 'hogyan?' konfliktusa; a feladat, szolgálat és a forrás delegálásában jelentkező nézeteltérés (például kinek milyen felelőssége van, időbeosztás). A feladat- és folyamatkonfliktus nehezen szétválasztható, tehát általában keverten jelennek meg, amelyet a kapcsolati konfliktusok érzelmi töltete színez, és gyakran megnehezíti az együttmúködő problémamegoldást. Megfelelő konfliktusmegoldási stratégia alkalmazásával ez a hatás csökkenthető lenne. Rahim [11] kétdimenziós elmélete szerint az alapján különíthetők el a konfliktuskezelési stratégiák, hogy mennyire veszik figyelembe az egyén saját érdekeit vagy a másik fél érdekeit. Az integráló konfliktuskezelési stílus mindkét fél érdekeit egyformán figyelembe veszi, és egyik félnek sem kell lemondania semmiról. Ez az úgynevezett nyertes-nyertes stratégia, amely azonban a legritkábban fordul elő az egészségügyi dolgozók között. Az alkalmazkodó stratégia látszólag csökkenti a konfliktus következtében kialakult feszültséget, de a személy saját érdekeit feladva alkalmazkodik, tehát hosszú távon negatív hatású a személyre nézve. A domináló stílus esetében a személy számára az együttmúködés nem fontos, versengő attitűd jellemzi. A domináló stílus egészségügyben való jelenléte a hierarchiával hozható összefüggésbe, tehát az alá-fölé rendeltségi viszony nemcsak a konfliktus forrásaként jelenik meg, hanem jelentősen befolyásolja az alkalmazott stratégiát és így a konfliktus kimenetelét is. Az eü.-i dolgozók igyekeztek a konfliktusmegoldás során mindkét fél érdekeit figyelembe venni. Ez a kompromisszumkeresö stratégia ugyanakkor lemondással jár, az érdekek 50-50\%-ban érvényesülnek. Mindezek alapján úgy tünhet, hogy az egészségügyben a kompromisszumra törekvés jellemző, de eredményeink szerint az elkerülő stratégia (teljesen + indirekt elkerülő) hasonló arányban fordul elő. Így a konfliktusok sok esetben megoldatlanok maradnak, aminek negatív hatása egyértelmú a szakirodalom alapján [4-6]. Az elemzett narratívákban a személyes negatív hatást említik a leggyakrabban, a betegellátásra gyakorolt hatás alulreprezentáltnak tünik, amely lehet egyfajta tagadás, elfedés következménye is. Az egészségügyi dolgozók önbeszámolója szubjektív, így az eredmény ennek a hatásnak az elfogadhatatlanságát tükrözi.

Eredményeink limitációja, hogy a jelenlegi, részletes elemzés 30 interjú alapján készült, valamint a nóvérek csoportja ugyanarról az osztályról került ki. Ugyanakkor a kialakított kategóriarendszer alkalmas keretet ad a további, nagyobb mintán alapuló elemzéshez, és számos hasonlóságot mutat a nemzetközi megfigyelésekkel [7].

Anyagi támogatás: A kutatás és a közlemény megírása anyagi támogatásban nem részesült.

Szerzői munkamegosztás: Cs. É., K. Á., P. J. N., K. Zs., Cs. M.: Hipotézisek kidolgozása. Cs. É.: Vizsgálat lefolytatása. Cs. É., K. Á.: Adatelemzés. Cs. É.: Kézirat megszövegezése. K. Á., P. J., Cs. M.: Kézirat szövegének javítása. Cs. M.: Kutatás menetének felügyelése. A cikk végleges változatát valamennyi szerző elolvasta és jóváhagyta.

Érdekeltségek: A szerzőknek nincsenek érdekeltségeik.

\section{Köszönetnyilvánítás}

Köszönetünket szeretnénk kifejezni minden, a kutatásban részt vevő orvosnak és nővérnek, valamint az interjúfelvételek elkészítésében részt vevő kollégáknak (Bori-Szabó Orsolya, Havancsák Rózsa, Katona Edina, Látos Melinda).

\section{Irodalom}

[1] Rahim, M. A., Bonoma, T. V.: Managing organizational conflict: A model for diagnosis and intervention. Psychol. Rep., 1979, 44, 1323-1344.

[2] Leever, A. M., Hulst, M. V., Berendsen, A. J., et al.: Conflicts and conflict management in the collaboration between nurses and physicians - A qualitative study. J. Interprof. Care, 2010, 24(6), 612-624.

[3] Kreitner, R., Kinicki, A.: Organizational behaviour (9th ed.). McGraw-Hill, New York, 2010.

[4] Patton, C. M.: Conflict in health care: A literature review. Internet J. Healthcare Admin., 2014, 9(1), 1-11.

[5] Almost, J., Wolff, A. C., Stewart-Pyne, A., et al.: Managing and mitigating conflict in healthcare teams: an integrative review. J. Adv. Nurs., 2015, 72(7), 1490-1505.

[6] Paradis, E., Whitehead, C. R.: Louder than words: power and conflict in interprofessional education articles, 1954-2013. Med. Educ., 2015, 49(4), 399-407.

[7] Kim, S., Buttrick, E., Bohannon, I., et al.: Conflict narratives from the health care frontline: A conceptual model. Conflict Resolution Quarterly, 2016, 33(3), 255-277. 
[8] Jehn, K. A., Mannix, E. A.: The dynamic nature of conflict: A longitudinal study of intragroup conflict and group performance. Acad. Manage. J., 2001, 44(2), 238-251.

[9] Le, J. K., Jarzabkowski, P. A.: The role of task and process conflict in strategizing. Br. J. Manag., 2014, 26(3), 439-462.

[10] O'Neill, T. A., Allen, N. J., Hastings, S. E.: Examining the "pros" and "cons" of team conflict: A team-level meta-analysis of task, relationship and process conflict. J. Hum. Performance, 2013, 26(3), 236-260.

[11] Rabim, M. A.: A measure of styles of handling interpersonal conflict. Acad. Manage. J., 1983, 26(2), 368-376.
[12] Leever, A. M., Hulst, M. V. D., Berendsen, A. J., et al.: Conflicts and conflict management in the collaboration between nurses and physicians - a qualitative study. J. Interprof. Care, 2010, 24(6), 612-624.

[13] Losa Iglesias, M. E., Becerro de Bengoa, Vallejo R.: Conflict resolution styles in the nursing profession. Contemp. Nurse, 2012, $43(1), 73-80$.

(Csupor Éva,

Szeged, Boldogasszony sgt. 21/6, 6725 e-mail: csupor.eva@gmail.com)

\section{Melléklet}

\section{"Egészségügyi dolgozók konfliktusai” kutatás \\ SZTE BTK Pszichológiai Intézet, 2015 \\ Interjúlevezetési útmutató}

\section{Bevezetö szavak, az adatfelvétel menetének ismertetése (lebet} saját szavakkal)

1. Köszönöm, hogy részt vesz ebben a kutatásban!

2. Nevem... Foglalkozásom... E kutatást végző team tagja vagyok.

3. Munkahelyi közösségeken belül létrejövő konfliktusok vizsgálatát végezzük. Az a reményünk, hogy ha sikerül jobban megérteni e konfliktusok belső mechanizmusát, akkor sikeresebb stratégiákat lesz módunk kidolgozni a konfliktusok megelőzésére és hatékony megoldására.

4. A kérdésekre nincsenek jó vagy rossz válaszok. A konkrét élményeire, tapasztalataira és személyes meglátásaira vagyunk kíváncsiak.

5. A vizsgálat szigorúan bizalmas. Ha ebbe ön is beleegyezik, rögzíteni fogom az interjút, hogy egyetlen részlet se kerülhesse el a figyelmünket, ám az így keletkező információt név nélkül fogjuk tárolni, és az interjúk elemzése is anonim módon történik.

6. Szabadon eldöntheti, hogy mely kérdésekre válaszol és melyekre nem.

7. Az interjú kkörülbelül 45 percig fog tartani.

8. Van-e valamilyen kérdése az interjú lefolyásával kapcsolatban?

\section{Ezt követöen ne felejtsïk el:}

Elolvastatni és aláíratni a résztvevókkel a beleegyezési nyilatkozatot!

Kitöltetni az adatlapot!

(Ő tölti ki, a szeme láttára írjuk rá az azonosítószámát.)

Bekapcsolni a felvevőt!

\section{Az interjú kezdése}

1. Mielőtt elkezdenénk, tisztázzuk, hogy mindannyian értjük ezt a fogalmat, hogy konfliktus. Tudjuk, hogy konfliktus bármikor felléphet az életünkben, és mindannyian átéltünk, illetve tanúi voltunk már mindenféle konfliktusnak, bármely banális és jelentéktelen konfliktusról legyen is szó.

2. Nagyon fontos felhívni arra a figyelmet, hogy nem akarunk önre erőltetni semmiféle előzetes fogalmat arról, hogy pontosan mit tekintsen konfliktusnak; inkább arra vagyunk kíváncsiak, hogy ön mit észlel és él át konfliktusként.

\section{A konfliktus leírása}

3. Talán kezdhetnénk azzal, hogy elmesél nekem egy olyan konfliktushelyzetet, amit ön személyesen átélt, vagy aminek tanúja volt.

4. Elmélyités (ha szükséges)

a) Mi körül robbant ki a konfliktus?

b) Mikor, mely pillanatban robbant ki a konfliktus?

c) Hogyan kezdődött a konfliktus?

d) Kik voltak érintve a konfliktusban? (Funkciójuk és szakmájuk szerint, semmiképpen sem név szerint! Konkrét személy neve nem lehet a felvételen!)

e) Hol zajlott le a konfliktus? (Általános helymegnevezés, például a kórteremben.)

\section{$A$ belyzet elemzése (a „miért”)}

5. Hogyan magyarázná ezt a konfliktust?

a) Mi váltotta ki a konfliktust?

b) Vannak-e egyéb tényezők, amik hozzájárultak a konfliktus kialakulásához?

i. elmélyíteni: Megelőzte-e a konfliktust valamely félreértés, kommunikációs zavar, külső nyomás, eltérő munkatempó, vagy eltérő szokások, érzelmi esemény, túlterheltség, az egész osztályt vagy szervezeti egységet megülő hangulat, a konfliktus résztvevői közötti korábbi ellentét stb.?

6. Az érzelmekről, az érzésekről beszélni

a) Direkt rákérdezés: Mit érzett a konfliktus során? vagy:

b) Indirekt kérdés (tükrözés): Úgy tünik, hogy önnek ez a helyzet nagyon nehéz/frusztráló/csüggesztő szituáció. Jól értem? vagy:

c) Indirekt kérdés (projektív kérdés): Egyesek a konfliktussal bizonyos érzelmeket kapcsolnak össze. Olyanokat, mint idegeskedés, frusztráció, harag stb. Másokra ez egyáltalán nem jellemző. Ön hogy áll ezzel?

\section{A konfliktus lefolyása}

7. Hogyan alakult a továbbiakban a konfliktus?

8. Megoldódott-e végül a konfliktus? És ha igen, hogyan?

a) Mit tett ön a konfliktus kezelésének érdekében? Mit tett ön a konfliktussal való szembenézés érdekében?

9. Elégedett-e azzal, ahogy a konfliktus végül megoldódott?

a) Tudna erről egy kicsit többet mondani? (Ha magától ezt nem teszi.)

10. Ön szerint mi segített a konfliktus megoldásában? a) Beszélt valakivel a konfliktusról? Kivel? Segített ez?

11. Akart volna-e igénybe venni valamilyen külső segítséget a konfliktus megoldása érdekében? Milyen fajta segítséget?

12. Készült-e a konfliktusról valamilyen írásbeli jegyzőkönyv? 
13. Ha a jövőben egy hasonló konfliktus lépne fel, ön hogyan próbálná meg kezelni?

\section{Lebetséges hatás}

14. Miben észlelte a konfliktus hatását:

a) önre? (Hangulat, munka, szakmai kapcsolatok stb.)

b) a teamre? (Hangulat, munka, szakmai kapcsolatok stb.)

c) a betegre? (Viselkedés, a gyógyító személyzettel szemben táplált bizalom, a gyógykezelés minősége stb.)

\section{Egyéb konfliktusok?}

15. Vannak-e egyéb olyan konfliktushelyzetek, amikröl szeretne beszélni? (Megjegyzés az interjúkészitó számára: Érdemes olyan példák után kutatni, amelyek az alapesettel ellentétes természetúek, például más személyekkel függenek össze, más okokra mennek vissza, más tárgyuk van.)

\section{Az interjú vége}

16. Ezzel ez az interjú itt lezárul. Mielőtt azonban befejeznénk, kíván-e még valamilyen, a beszélgetés során felmerült részletre még egyszer visszatérni?

Vagy esetleg van-e olyan egyéb részlet, amivel kiegészíteni kívánja az eddig elhangzottakat?

17. Szeretném önnek megköszönni ezt az érdekes és gazdag beszélgetést!

a) Ha bármilyen kérdése van a késóbbiekben is a kutatással kapcsolatban, itt az e-mail címem, nyugodtan keressen!

b) Elemezni fogjuk ezeket az eredményeket, és a vizsgálat végeredményét nyilvánosságra is fogjuk hozni. Amenynyiben érdeklik ezek a következtetések, szívesen a rendelkezésére bocsátjuk őket!

\title{
MEGHÍVó
}

\section{A Szent Margit Kórház Intézeti Tudományos és Kutatás Etikai Bizottsága tisztelettel meghívja az érdeklődőket a következő tudományos ülésére, melyet Központi Gyógyszertár és a Központi Labor közösen rendez.}

\author{
Időpont: 2017. április 27. (csütörtök) 14.30 óra \\ Helyszín: Szent Margit Kórház - 1032 Budapest III., Bécsi út 132. \\ „A" épület, I. emelet, Konferenciaterem
}

Üléselnök: Prof. Dr. Berényi Marianne

\section{Program:}

Dr. Cseh Ibolya fögyógyszerész: Klinikai gyógyszerészet - gyógyszerészi gondozás

10 perc

Dr. Borza Erzsébet (meghívott előadó, Veszprém megyei Csolnoky Ferenc Kórház):

Gyógyszerelés gyógyszerész által történő áttekintése a nemzetközi gyakorlatban

15 perc

Dr. Szabó Alexandra: Gyógyszerészi feladatok a Kardiológiai Osztályon

15 perc

Dr. Wanderlich Béla: Mérést befolyásoló tényezők, preanalitikai hibák és hibaforrások

10 perc

Gyurcsák Gyöngyi: POCT-preanalitika jelentősége

10 perc

Bokányi Krisztina: Hemolitikus minták értékelése, mintavétel jelentősége

10 perc 